\title{
Postglacjalne zmiany środowiska przyrodniczego na Wysoczyźnie Dobrzyńskiej zapisane w profilu osadów biogenicznych w Piotrkowie
}

\author{
Post-glacial changes in the natural environment on Dobrzyń Plateau recorded \\ in the profile of biogenic sediments in Piotrkowo
}

\author{
Wojciech Gamrat, Leon Andrzejewski, Iwona Krześlak \\ Katedra Geomorfologii i Paleogeografii Czwartorzędu, Uniwersytet Mikołaja Kopernika, Toruń,wojgam@umk.pl
}

Zarys treści: Stanowisko Piotrkowo położone jest w zachodniej części Wysoczyzny Dobrzyńskiej. Szczegółowa analiza rdzenia Piotrkowo I pozwoliła na rekonstrukcję warunków środowiska w okresie ostatnich kilkunastu tysięcy lat. Uzyskane wyniki wskazują na trzy odmienne etapy warunków sedymentacji osadów organicznych, dwa jeziorne i jeden lądowy. Pierwszy etap, jeziora plenivistuliańskiego, zapisany jest w postaci mułków organicznych, częściowo laminowanych. Drugi obejmuje jezioro holoceńskie, wypełniane miąższymi pokładami gytii węglanowej. Ostatni etap, późnoholoceński, stanowi zapis dynamicznych zmian poziomu wody utrwalonych w osadach lądowych wykształconych w postaci silnie rozłożonego torfu i namułu organicznego.

Słowa kluczowe: analiza pyłkowa, plenivistulian, holocen, Wysoczyzna Dobrzyńska

\begin{abstract}
Piotrkowo site is located in the western part of the Dobrzyń Plateau. Detailed pollen analysis of the Piotrkowo I core enabled a reconstruction of environmental conditions change over last several thousand years. The results indicated three different stages of the organic sedimentation, two limnic and one terrestrial. The first stage of Plenivistulian age lake is recorded in organic silt sediment, partly laminated. The second stage contains traces of Holocene age lake preserved in carbonate gyttja sediment. The last phase includes a record of dynamic changes in the groundwater level recorded in terrestrial sediments - highly decomposed peat and organic loam.
\end{abstract}

Key words: pollen analysis, Plenivistulian, Holocene, Dobrzyń Plateau

\begin{abstract}
Wstęp
Osady organiczne stanowią unikatowe archiwum informacji na temat zmian środowiska przyrodniczego (Tobolski 2000). Korzystając z analiz paleoekologicznych, można zrekonstruować ewolucję różnych form rzeźby polodowcowej, m.in. rynien subglacjalnych. Przykładem formy o złożonej ewolucji jest rynna rzeki Lubianki. Wykonane w niej badania pozwalają włączyć się do szerokiej i stale aktualnej dyskusji na temat historii jezior polodowcowych na obszarze młodoglacjalnym. Zagadnienia dyskusyjne poruszane w niniejszym artykule dotyczą m.in. różnych generacji i czasu funkcjonowania jezior oraz procesów kształtujących formy rynnowe w ich postglacjalnej
\end{abstract}

historii. Były one podejmowane przez szereg badaczy (m.in. Niewiarowski 1959, 1968, 1986, 1988, 1989, 1993, 1995a, Galon 1983, Andrzejewski 1994, Kozarski 1994, Marks 1996, Błaszkiewicz 2005, 2007, Andrzejewski i in. 2009).

Jedną z szeroko wykorzystywanych metod badawczych jest analiza pyłkowa, która była stosowana przy opracowywaniu genezy i ewolucji m.in. Jeziora Biskupińskiego (Niewiarowski 1995b), jeziora Gościąż (Ralska-Jasiewiczowa i in. 1998), Jeziora Miłkowskiego (Wacnik 2009), jezior kórnicko-zaniemyskich (Wojciechowski 2000), jeziora Perespilno (Bałaga 2004, Szeroczyńskia, Zawisza 2007), jezior lednickich (Tobolski red. 1991) czy jeziora Wigry (Rutkowski, Krzysztofiak 2009). 
Wyniki zamieszczone w niniejszym artykule nawiązują do wymienionych prac, zwłaszcza w kontekście istnienia różnowiekowych generacji jezior.

\section{Obszar badań}

Obszar badań położony jest w strefie pojezierzy Polski północnej, ukształtowanej podczas stadiału głównego ostatniego zlodowacenia (Kondracki 1998). W krajobrazach tej strefy dominują płaskie i faliste wysoczyzny morenowe, urozmaicone formami marginalnymi oraz licznymi formami związanymi z erozyjną i akumulacyjną działalnością wód roztopowych (Niewiarowski 1959, 1968), m.in. rynnami polodowcowymi, częściowo wypełnionymi osadami organicznymi. Jedną $\mathrm{z}$ takich form jest rynna rzeki Lubianki, znajdująca się w północno-zachodniej części Wysoczyzny Dobrzyńskiej, której północna część stała się przedmiotem szczegółowych prac (ryc. 1).

Profil Piotrkowo I pobrany został w południowej części obszaru badań, z dna rynny w sąsiedztwie rzeki Lubianki (ryc. 2). O wyborze tego miejsca zadecydowała jego dostępność oraz znaczna miąższość osadów organicznych.

\section{Metody badań}

W ramach prac terenowych wykonano szczegółowe kartowanie geomorfologiczne i geologiczne obszaru badań w skali 1:25 000. Na ich podstawie wykonano mapę geomorfologiczną (ryc. 2). W rynnie rzeki Lubianki obok równin biogenicznych wyróżniono kemy oraz dwa poziomy glacjalne $\mathrm{z}$ ukierunkowanymi formami drumlinopodobnymi (Deneko, Andrzejewski 2012).

Do szczegółowych badań laboratoryjnych pobrano sondą Livingstone'a w modyfikacji Więckowskiego (Więckowski 1966) profil osadów organicznych Piotrkowo I o nienaruszonej strukturze.
Badania laboratoryjne skupione były głównie na analizie pyłkowej, której poddano 141 próbek. Ich macerację przeprowadzono zgodnie z zaleceniami Dyakowskiej (1959) oraz Dybovej-Jachowicz i Sadowskiej (2003). Polegała ona na traktowaniu osadu 10-procentowym kwasem solnym $(\mathrm{HCl})$ i 10-procentowym ługiem potasowym $(\mathrm{KOH})$ oraz wykonaniu acetolizy Erdtmana, a także wykorzystaniu zimnego 40-procentowego kwasu fluorowodorowego (HF). Zliczanie sporomorf i wykreślenie diagramu pyłkowego wykonano w programie PolPal (Nalepka, Walanus 2003).

Osady organiczne scharakteryzowano, posiłkując się oznaczeniem zawartości materii organicznej, związków węglanowych oraz niewęglanowej pozostałości mineralnej. W tym celu wykorzystano metodę prażenia Bengstone'a-Ennela (1986).

Określenie wieku badanych osadów oparto m.in. na wykonanym datowaniu radiowęglowym metodą AMS w Poznańskim Laboratorium Radiowęglowym. Materiał do badań przygotowany został zgodnie z zaleceniami Walanusa i Goslara (2009). Stanowił on fragment osadu organicznego opisanego jako mułek organiczny (Poz-46879). Uzyskaną datę poddano kalibracji w programie CalPal.

\section{Wyniki badań w profilu Piotrkowo I}

Badane osady wykształcone zostały w postaci serii zróżnicowanych osadów organogenicznych (tab. 1).

Wyniki analizy pyłkowej pozwoliły na wyróżnienie siedmiu lokalnych poziomów pyłkowych (L PAZ) z dziewięcioma lokalnymi podpoziomami (L PASZ). Ich wydzielenie oparto na zmiennym udziale poszczególnych krzywych procentowych drzew i krzewów (AP) oraz wybranych taksonów zielnych, a także analizach numerycznych, uzupełnionych datowaniem radiowęglowym. Dodatkowo wykonano korelację uzyskanych L PAZ $\mathrm{z}$ wynikami innych prac $\mathrm{w}$ najbliższym otoczeniu o zasięgu lokalnym i regionalnym (m.in. Noryśkiewicz B. 1982,

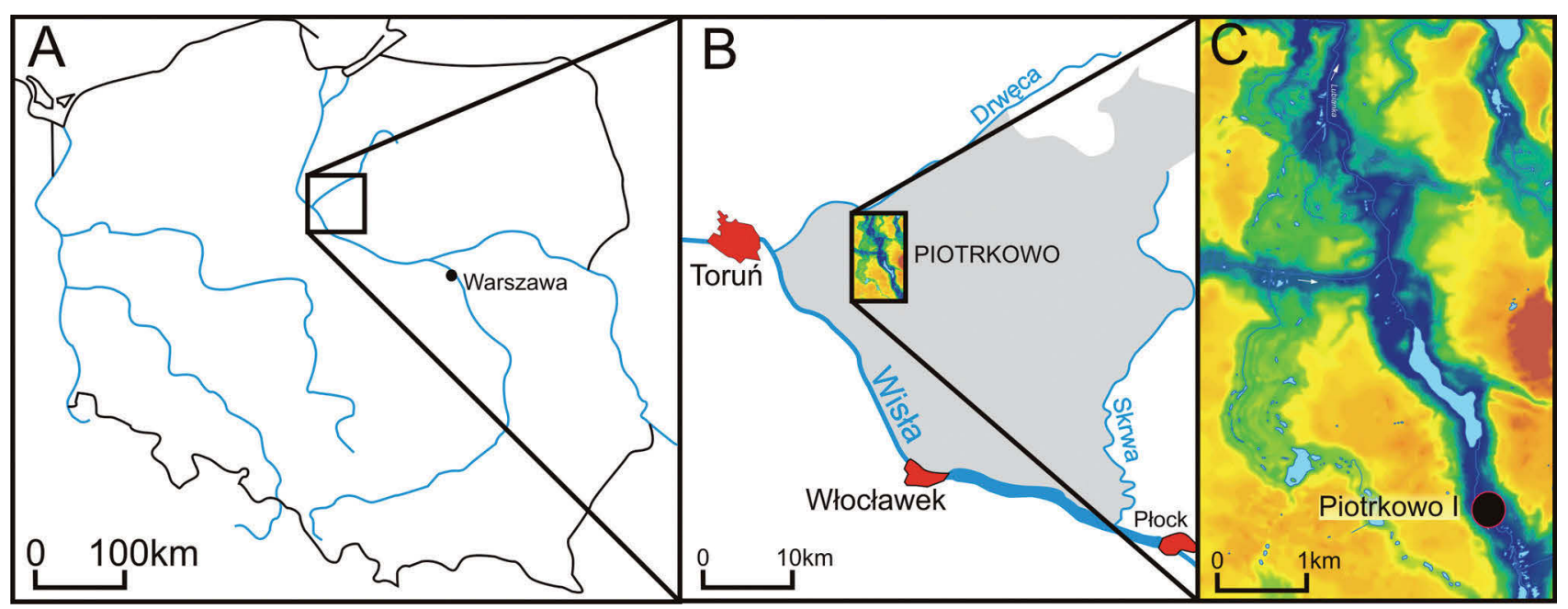

Ryc. 1. Lokalizacja profilu Piotrkowo I: A - Polska, B - ziemia dobrzyńska, C - północna część rynny rzeki Lubianki

Fig. 1. Location of the Piotrkowo I profile: A - Poland, B - Dobrzyń Land, C - northern part of the Lubianka river subglacial channel 


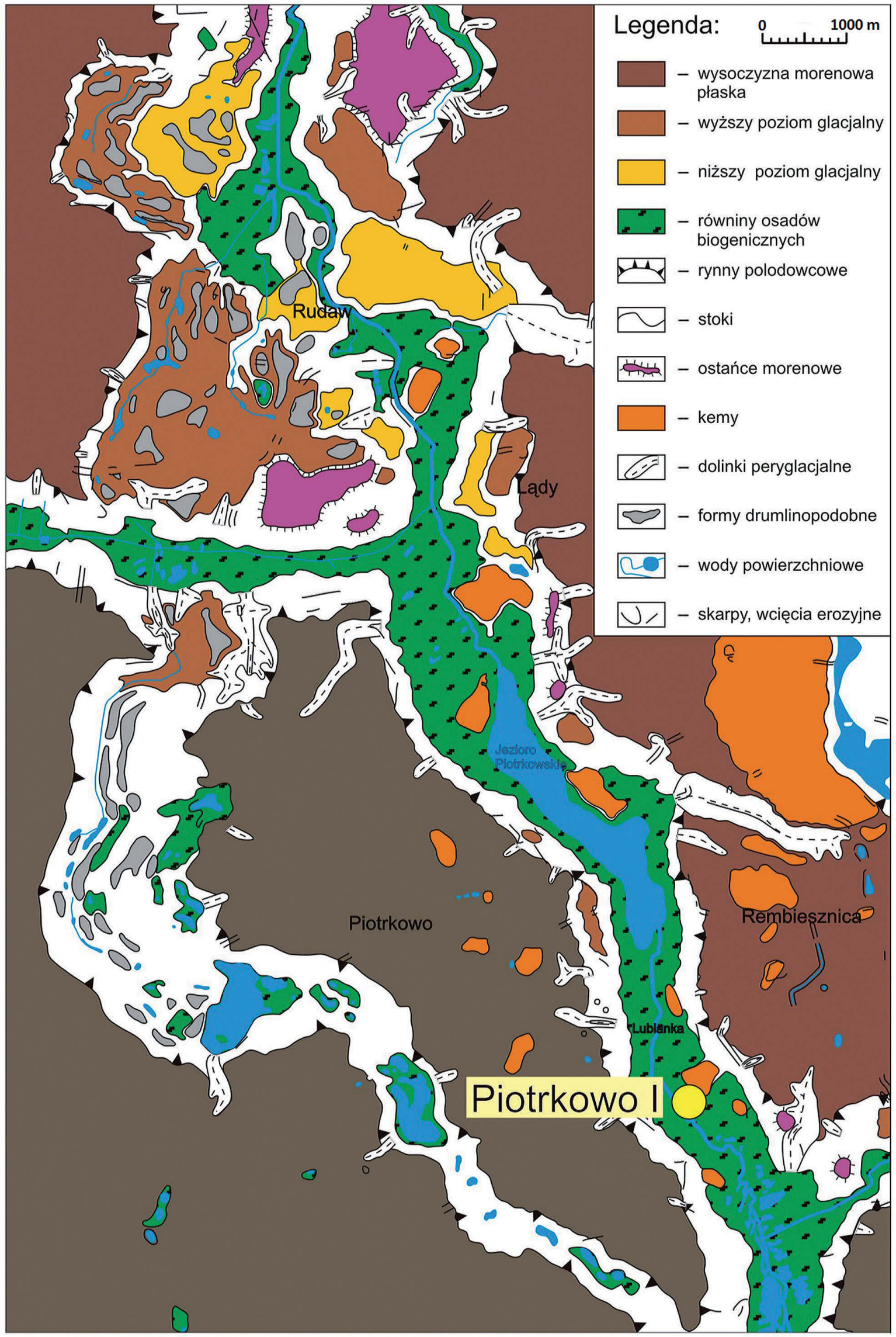

Ryc. 2. Mapa geomorfologiczna północnej część rynny rzeki Lubianki i jej otoczenia

Fig. 2. Geomorphological map of the northern part of the Lubianka river subglacial channel and its surroundings 
Tabela 1. Charakterystyka osadów profilu Piotrkowo I

Table 1. Characteristics of sediment profile Piotrkowo I

\begin{tabular}{|c|c|c|c|c|}
\hline \multirow{3}{*}{$\begin{array}{c}\text { Głębokość } \\
\text { (cm) }\end{array}$} & \multirow{3}{*}{ Osad } & \multicolumn{3}{|c|}{ Zawartość związków } \\
\hline & & Organicznych & Węglanowych & Mineralnych \\
\hline & & \multicolumn{3}{|c|}{$[\%]$} \\
\hline $0-85$ & namuł organiczny, ciemnoszary & $9,2-41,6$ & $>3,5$ & $55,5-88,8$ \\
\hline $85-87$ & piasek, drobno- i średnioziarnisty & $6,6-2,8$ & $>0,8$ & $92,6-96,6$ \\
\hline $87-120$ & namuł organiczny, ciemnoszary & $37,1-40,7$ & $>2,0$ & $57,9-61,0$ \\
\hline $120-212$ & silnie rozłożony torf, ciemnobrązowy & $54,0-88,4$ & $2,0-4,2$ & $9,6-23,3$ \\
\hline $212-214$ & piasek, drobno- i średnioziarnisty & 5,2 & 0,3 & 94,5 \\
\hline $214-840$ & gytia węglanowa, jasnoszara & $6,2-14,1$ & $56,2-86,8$ & $5,4-31,7$ \\
\hline $840-890$ & gytia ilasta, szara & $6,8-14,0$ & $18,6-48,9$ & $44,0-74,5$ \\
\hline $890-1440$ & mułek organiczny, szary, miejscami laminowany $(1198-1205 \mathrm{~cm})$ & $2,2-6,4$ & $8,2-23,4$ & $73,9-85,3$ \\
\hline
\end{tabular}

1987, Ralska-Jasiewiczowa i in. 1998, Milecka 2005, Nalepka 2005, Noryśkiewicz A.M. 2006, 2013, Andrzejewski i in. 2009, Filbrandt-Czaja 2009, Gamrat 2011, Karasiewicz i in. 2011, 2014, Wysota, Noryśkiewicz B. 2011).

Poziom $\mathrm{P}_{\mathrm{I}}-1$, NAP-Pinus-Betula (900-1430 cm) wyróżniono na podstawie bardzo wysokiego udziału roślin zielnych (NAP) - około $20,0 \%$ - oraz wysokich wartości sosny (Pinus) i brzozy (Betula) (ryc. 3). Obecne były ziarna pyłku światłożądnych taksonów krzewiastych: przęśl (Ephedra), rokitnik zwyczajny (Hippophäe rhamonides), jałowiec pospolity (Juniperus communis), brzoza karłowata (Betula nana) - i zielnych: dębik ośmiopłatkowy (Dryas octopetala), posłonki (Helianthemum). Istotna dla interpretacji okazała się bardzo niska frekwencja oraz znaczny udział sporomorf zniszczonych i redeponowanych - zarówno ziarna pyłku ciepłolubnych i bardziej wymagających drzew (np. olsza Alnus czy lipa - Tilia), jak i redeponowanych sporomorf neogeńskich (np. Pterocraya, Nyssa czy Taxodium - na diagramie suma oznaczona jako Rebedded) i bruzdnic (Hystix) (ryc. 3). Dodatkowo obecne były cenobia glonów Pediastrum kawraiskyi, które znane są z osadów zimnych zbiorników wodnych okresu późnego glacjału, m.in. z obszaru Czech i Sudetów (Komarek, Jankovska 2003). Uzyskane spektra pyłkowe pozwoliły wskazać na zimny okres powstawania badanych osadów. Jednoznaczne określenie wieku osadów na schyłkowy okres plenivistulianu możliwe było poprzez korelację ich z utworami, przeważnie mułkowymi, znanymi z innych stanowisk z obszaru m.in. Polski (Niewiarowski 1995b, Wacnik 2009), Danii (de Klerk 2004, Morrtensen i in. 2011) czy Litwy (Stančikaitè i in. 2008).

Zmienność osadu, dominujących taksonów drzew i krzewów oraz koncentracji ziaren pyłku pozwoliły na wyróżnienie trzech podpoziomów: Pinus (1210-1430 $\mathrm{cm})$, Betula $(1150-1210 \mathrm{~cm})$ i NAP (900-1150 cm) (ryc. 3). Podpoziomy dokumentują zróżnicowanie warunków sedymentacji osadów limnicznych. Osady pierwszego podpoziomu wykształcone są w postaci masywnych, szarych mułków organicznych. W spektrach pyłkowych zaznacza się bardzo niska koncentracja ziaren pyłku, wśród których dominuje sosna, przy niewielkim udziale brzozy, i gatunki zielne typowe dla otwartych siedlisk o charakterze tundrowym, tj. bylic (Artemisia), posłonków, komo- sowatych (Chenopodiaceae), dębika ośmiopłatkowego, skalnicy (Saxifraga) i widliczki ostrozębnej (Selaginella selaginoides). Istotny jest również znaczny udział zniszczonych i redeponowanych ziaren pyłku. Podkreślają one niekorzystne warunki dla rozwoju roślinności w warunkach klimatu zimnego i suchego oraz intensywnej działalności procesów denudacyjnych.

Drugi podpoziom obejmuje szare, masywne osady mułkowe miejscami laminowane (zwłaszcza na głębokości 1198-1205 cm). Charakteryzuje je wyższa koncentracja ziaren pyłku i mniejszy udział sporomorf zniszczonych oraz redeponowanych. Wśród drzew i krzewów dominuje brzoza i brzoza karłowata. Przypuszczalnie był to wynik polepszenia się warunków klimatycznych, skutkujących większą zwartością pokrywy roślinnej i intensywniejszym pyleniem.

Podobnie do pierwszego, trzeci podpoziom jest wykształcony w postaci masywnych, szarych mułków. W spektrach pyłkowych udokumentowany jest wysoki udział sosny i jałowca oraz NAP (non-arborum pollen suma roślin zielnych), w tym szczególnie duży traw i baldaszkowatych (Apiaceae). Ponownie spada koncentracja sporomorf oznaczalnych oraz zwiększa się udział ziaren zniszczonych i redeponowanych. Otrzymane spektra pyłkowe pozwalają na stwierdzenie, że opisywane osady powstawały w warunkach chłodniejszych od poprzedzających je z podpoziomu drugiego.

Poziom P $\mathrm{P}_{\mathrm{I}}-2$, Pinus-Betula $(790-900 \mathrm{~cm})$, zbudowany jest ze zróżnicowanych osadów w postaci szarego, masywnego mułku oraz gytii ilastej i węglanowej. Uzyskane spektra pyłkowe charakteryzuje naprzemienna dominacja sosny i brzozy (ryc. 3) oraz znacznie niższy udział sumy roślin zielnych (NAP). Zanik krzywych jałowca i brzozy karłowatej oraz pojawienie się stałych krzywych bardziej wymagających drzew i krzewów, tj. leszczyny (Corylus), dębu (Quercus), wiązu (Ulmus) i olszy, świadczą o następującej wówczas przebudowie składu gatunkowego panujących formacji roślinnych. Taki skład spektrów pyłkowych pozwala łączyć niniejszy poziom z okresem preborealnym.

Z uwagi na duże zróżnicowanie wykształcenia osadów w badanym fragmencie rdzenia, wykonano datowanie radiowęglowe w stropie osadów mułkowych. Otrzymana data $16810 \pm 100 \mathrm{BP}$ (po kalibracji $20028 \pm 293 \mathrm{BP}$ ) 


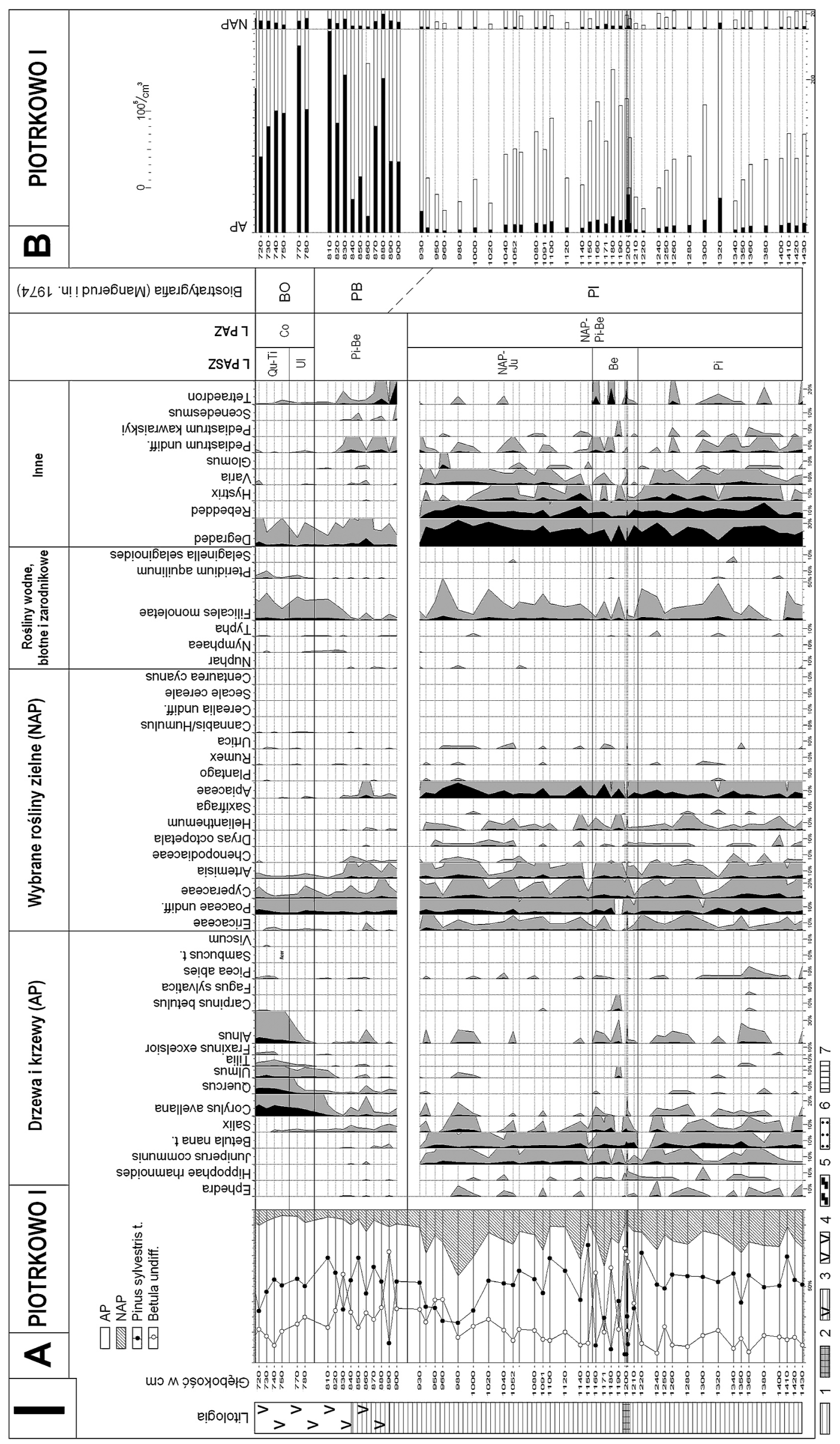




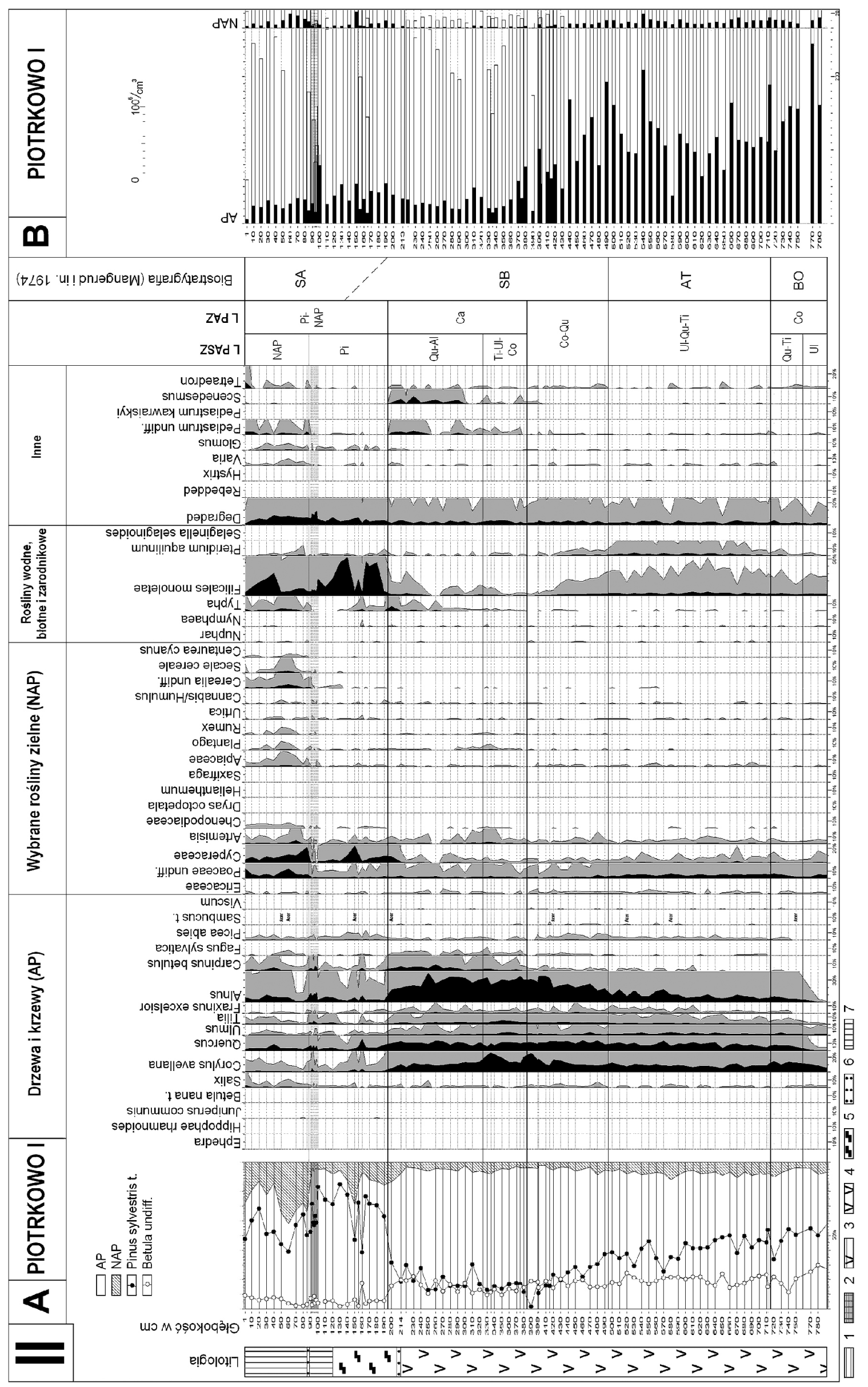


wskazuje na znacznie starsze osady z okresu schyłkowego plenivistulianu, natomiast wyniki analizy pyłkowej na znacznie młodszy wiek, tj. okres preborealny. Tak duża różnica wieku jest prawdopodobnie efektem wzbogacenia osadów jeziornych z wczesnego holocenu materiałem redeponowanym.

Poziom $\mathrm{P}_{\mathrm{I}}-3$, Corylus $(712-790 \mathrm{~cm})$, wykształcony jest $\mathrm{W}$ postaci silnie węglanowej gytii. Wydzielenie tego poziomu oparto na podstawie wzrastającego udziału leszczyny - średnio 10,2\% (lokalne maksimum 15,0\%) - oraz stopniowego spadku krzywej sosny i brzozy. Obecne są również stałe krzywe dębu, wiązu, lipy, olszy, jesionu (Fraxinus) i świerka (Picea) (ryc. 3). Udział NAP wynosi kilka procent, nie przekraczając 10,0\%. Taki skład spektrów pyłkowych pozwala korelować niniejszy poziom z okresem borealnym. Zaznaczająca się wyraźna dwudzielność poziomu umożliwiła wydzielenie dwóch podpoziomów: Ulmus $(750-790 \mathrm{~cm})$ i Quercus-Tilia $(712-750 \mathrm{~cm})$. Podział ten nawiązuje do zapisu przebiegu ekspansji leszczyny na obszarze Polski, szerzej opisanej przez Mitok-Szpiganowicz i in. (2004).

Kolejny poziom $\mathrm{P}_{\mathrm{I}}-4$, Ulmus-Quercus-Tilia (490-712 $\mathrm{cm}$ ), obejmuje fragment rdzenia zbudowany z gytii węglanowej. Jego wyróżnienie oparto na wysokim udziale wiązu, dębu i lipy. Wspomniane taksony, wraz z jesionem, były najpewniej składnikami lasów typu Quercetum mixtum. Ich udział, wraz z pojawieniem się ziaren pyłku klonu (Acer), jemioły (Viscum) i bzu (Sambucus), pozwala na korelację niniejszego poziomu z okresem atlantyckim. Obecność sporomorf jemioły świadczy o bardzo ciepłych sezonach letnich ze średnią temperaturą powyżej $16^{\circ} \mathrm{C}$ (Granoszewski i in. 2004). Nastąpiło wówczas najlepsze dopasowanie szaty roślinnej do warunków edaficznych - okres mezokratyczny holocenu (Latałowa 2003). Udział roślin zielnych na diagramie wynosi kilka procent. Po raz pierwszy pojawiają się zwiększone ilości spor orlicy pospolitej (Pteridium aquilinum), której towarzyszą ziarna babek (Plantago), pokrzywy (Urtica) oraz konopi/chmielu (Cannabis/Humulus), a także pierwsze ziarno w typie zbóż (Cerealia). Traktować to można jako dowód ingerencji człowieka w środowisko naturalne (Madeja $i$ in. 2004).

Poziom $\mathrm{P}_{\mathrm{I}}-5$, Corylus-Quercus (380-490 cm), również wykształcony jest w postaci gytii węglanowej. Wydzielony został w oparciu o wzrastający udział leszczyny (absolutne maksimum 26,0\%), dębu, lipy, wiązu, jesionu i olszy. Jednocześnie systematycznie spada udział sosny i brzozy. Pojawia się stała krzywa graba (Carpinus), wskazująca na początek ekspansji tego drzewa, która na sąsiedniej ziemi chełmińskiej wydatowana została na młodszą część okresu subborealnego (Noryśkiewicz A.M. 2008, 2013). Udział roślin zielnych wyniósł kilka procent.

Poziom P $\mathrm{I}$-6, Carpinus (190-380 cm), charakteryzuje się wzrostem udziału graba, średnio ponad 3,0\%, z absolutnym maksimum 9,0\% (ryc. 3). Badany fragment rdzenia zbudowany jest z gytii węglanowej, która na głębokości $214 \mathrm{~cm}$ przykryta jest dwucentymetrową warstwą piasku. Powyżej osadów piaszczystych znajduje się silnie rozłożony torf. Na diagramie pyłkowym obecne są wysokie krzywe leszczyny, dębu, wiązu, lipy, jesionu, buka (Fagus) i olszy. Pozwoliły one na wyróżnienie dwóch podpoziomów - Tilia-Ulmus-Corylus (320-380 cm) i Quercus-Alnus (190-320 cm), zawierających zapis wymiany gatunkowej w drzewostanie, tj. $\mathrm{z}$ wysokiego udziału leszczyny, wiązu i lipy na dąb i grab. Taki zapis pyłkowy wskazuje na obecność lasów typu Quercetum mixtum wzbogaconych o składnik grabowy i, w mniejszym stopniu, bukowy. W miejscach wilgotnych dominowała wówczas olsza, której krzywa na diagramie przekraczała średnią wartość $20 \%$. Obraz pyłkowy wskazywać może na subborealny wiek osadów. Podobnie zapis pyłkowy znajduje się m.in. w profilu Zbójenko (Karasiewicz i in. 2011) i Gronowo (Gamrat 2011). Udział roślin zielnych wynosi kilka procent, wzrastając do kilkunastu powyżej głębokości $212 \mathrm{~cm}$. Koreluje to ze zmianą osadu z wodnego na lądowy. Szczególnie dobrze jest to widoczne na przykładzie krzywej turzycowatych (Cyperaceae).

Wśród roślin wodnych, błotnych i zarodnikowych oraz palinomorf niepyłkowych, zwłaszcza w drugim podpoziomie, zaznacza się stały udział cenobiów glonów Pediastrum i Scenedesmus. W stropowej części opisywanego fragmentu rdzenia pojawiają się stałe krzywe pałek (Typha) i paproci (Filicales monolete) oraz pojedyncze ziarna pyłku grzybieni (Nympheacea) i grążeli (Nuphar). Obecność tych taksonów dokumentuje silnie zarastający zbiornik wodny z dobrze rozwiniętą strefą szuwarową.

Zmiana osadu z wodnego (gytia) na lądowy (silnie rozłożony torf) zaznacza się tylko w przebiegu sumarycznej krzywej roślin zielnych (NAP), w tym turzycowatych. Brak tego śladu w udziale drzew i krzewów (AP) oraz taksonów z grupy roślin wodnych, błotnych i zarodnikowych oraz palinomorf niepyłkowych. Wskazuje to na dobry zapis sukcesji roślinnej o charakterze regionalnym w badanych osadach. Podobna sytuacja została opisana np. w osadach ze stanowiska Retno (Karasiewicz i in. 2014), gdzie na osadach torfowych (środowisko lądowe) odłożona został warstwa mułku (środowisko wodne), na której ponownie zaczął narastać torf. Pomimo tak znacznego zróżnicowania osadów zapis pyłkowy nie uległ istotnym zmianom, zachowując ciągłość krzywych AP.

Ostatni poziom $\mathrm{P}_{\mathrm{I}}-7$, Pinus-NAP $(0-190 \mathrm{~cm})$, wykształcony został w różnych typach osadów lądowych. Do głębokości $120 \mathrm{~cm}$ obecny jest silnie rozłożony torf, powyżej którego zalega namuł organiczny przewarstwiony piaskiem na głębokości $85-87 \mathrm{~cm}$. Poziom ten wyróżniono na podstawie krzywej sosny i sumy roślin zielnych (NAP), które osiągają tu swoje absolutne maksima. Jednocześnie minimalny udział notuje brzoza, a spadek notują krzywe: leszczyny, dębu, wiązu, lipy, jesionu, graba i buka. Tak mało charakterystyczny zapis pyłkowy uniemożliwia jednoznaczne określenie wieku osadu. Wyraźna dwudzielność badanego poziomu pozwoliła wyodrębnić podpoziomy Pinus $(85-180 \mathrm{~cm}) \mathrm{z}$ dominacją sosny i NAP $(0-85 \mathrm{~cm})$ z przewagą roślin zielnych.

Wśród roślin zielnych zanotowano najwyższy udział taksonów wiązanych ze wzmożoną działalnością człowie- 
ka (Behre 1981) m.in.: babki, szczawiu (Rumex), konopi/ chmielu, chabra bławatka (Centaurea cyanus) czy zbóż (Cerealia), w tym żyta zwyczajnego (Secale cereale). Towarzyszyła temu stała krzywa grzyba typu Glomus, interpretowanego jako wskaźnik działalności człowieka (van Geel $i$ in. 2003).

W przedstawianym poziome istotny dla interpretacji jest przebieg krzywych z grupy roślin wodnych, błotnych i zarodnikowych. Na szczególną uwagę zasługuje naprzemienny przebieg krzywej paproci oraz pałek, bobrka trójlistkowego, grążeli i grzybieni. Wysoki udział paproci uważany jest za oznakę obniżenia się zwierciadła wód gruntowych i przesuszenia osadu (Noryśkiewicz A.M. 2006, Wysota, Noryśkiewicz B. 2011). W otrzymanym diagramie pyłkowym widoczne są trzy kulminacje krzywej paproci, poprzedzone i przedzielone trzema kulminacjami krzywej pałek oraz obecnością ziaren pyłku bobrka, grzybieni i grążeli. Dokumentuje to trzy etapy wahań poziomu wody, co z uwagi na bliskość rzeki Lubianki wiązać można ze zmianami jej przepływów. Genezę tych zmian w drugim podpoziomie wyjaśnić można działalnością człowieka.

\section{Wnioski}

Analizy osadów organicznych stały się podstawą rekonstrukcji zmian środowiska przyrodniczego najbliższej okolicy stanowiska Piotrkowo.

Osady najstarsze wykształcone są $\mathrm{w}$ postaci masywnych mułków organicznych z wyraźną laminacją na głębokości 1198-1205 cm. Ich genezę wiązać można $\mathrm{z}$ obecnością zbiornika wodnego w chłodnym klimacie schyłkowego plenivistulianu. Zbiornik ten miał prawdopodobnie charakter zastoiskowy. Zwiększona koncentracja ziaren pyłku oraz dominacja brzozy wskazują, że w momencie depozycji osadów laminowanych warunki siedliskowe uległy nieznacznej poprawie (wzrost wilgotności i temperatury).

Powyżej osadów mułkowych znajdują się serie gytii mineralnej. Początek ich sedymentacji określono palinologicznie na okres preborealny. Wskazuje to na obecność luki stratygraficznej obejmującej kilka tysięcy lat (cały okres późnego glacjału) oraz istnienie dwóch generacji jezior. Podobną sytuację dla Jeziora Biskupińskiego opisał Niewiarowski (1995b), gdzie na osadach mułkowych wieku plenivistuliańskiego odkładały się allerödzkie gytie. Późnoglacjalny hiatus w osadach jest przypuszczalnie efektem zimnych i suchych warunków klimatycznych, charakterystycznych dla strefy peryglacjalnej, lub erozji rzecznej. Dopiero we wczesnym holocenie wody uwalniane $\mathrm{z}$ pogrzebanych brył martwego lodu i/lub lodu zimowego pozwoliły na powstanie „młodszego” zbiornika wodnego.

Sedymentacja jeziorna trwała nieprzerwanie do okresu subborealnego. Powstały wówczas miąższe pokłady gytii ilastej $(840-890 \mathrm{~cm})$ i silnie węglanowej (214-840 $\mathrm{cm}$ ), dokumentującej zapis pyłkowy sukcesji roślinnej charakterystycznej dla środkowej części holocenu. Istotna zmiana nastąpiła na głębokości $214 \mathrm{~cm}$, na której opisano dwucentymetrową warstwę piasku podścielającego silnie rozłożony torf. Najpewniej doszło wtedy do zmian hydrologicznych w północnej części rynny Lubianki związanych $\mathrm{z}$ naturalnym procesem wypełnienia misy jeziornej oraz wykształceniem się koryta rzeki. Obecność warstwy piaszczystej dokumentować może niewielki hiatus, który nie został zarejestrowany w zapisie pyłkowym.

Wyraźna zmiana na diagramie pyłkowym widoczna jest powyżej głębokości $190 \mathrm{~cm}$. Nastąpił wówczas spadek większości krzywych AP, z równoczesnym wzrostem udziału sosny i NAP (ryc. 3). Wynikiem takich zmian jest mało charakterystyczny zapis pyłkowy pozwalający określić wiek osadów na późny holocen. Przyczyną były wahania poziomu wody, których trzy fazy udokumentowane są w zapisie krzywych roślin wodnych, błotnych i zarodnikowych. Dodatkowo nałożył się na nie wpływ działalności człowieka, co szczególnie dobrze widoczne jest w zapisie pyłkowym podpoziomu $\mathrm{P}_{\mathrm{Ib}}$-NAP.

Najistotniejszym elementem rekonstrukcji postglacjalnych zmian środowiska przyrodniczego okazały się osady spągowe - obecność dwóch generacji jezior (plenivistuliańskiego i holoceńskiego) oraz stropowe zapis wahań poziomu wód w okresie późnego holocenu. Udokumentowane trzy fazy rozwoju, dwie jeziorne i lądowa, pozwalają włączyć się do dyskusji dotyczącej postglacjalnej ewolucji rynien polodowcowych.

\section{Literatura}

Andrzejewski L., 1994. Ewolucja systemu fluwialnego doliny dolnej Wisły w późnym vistulianie i holocenie na podstawie wybranych dolin jej dopływów. Wyd. UMK, Toruń.

Andrzejewski L., Gamrat W.W., Noryśkiewicz B., 2009. Zarys ewolucji środowiska przyrodniczego okolic Gronowa w okresie późnego glacjału i holocenu w świetle badań palinologicznych. W: L. Kasprzak (red.), Badania podstawowe i aplikacyjne w naukach geograficznych. Wyd. UAM, Poznań: 235-240.

Bałaga K., 2004. Changes of vegetation in Lake Perespilno environs (Lublin Polesie) in the Late Glacial and Holocene. Acta Palaeobotanica 44(2): 147-166.

Behre K.E., 1981. The interpretation of anthropogenic indicators in pollen diagrams. Pollen et Spores 23: 225-245.

Bengstson L., Ennel M., 1986. Chemical analysis. W: B.E. Berglund (red.), Handbook of Holocene Paleoecology and Palaeohydrology. John Wiley \& Sons Ltd., Chichester: 423-451.

Błaszkiewicz M., 2005. Późnoglacjalna i wczesnoholoceńska ewolucja obniżeń jeziornych na Pojezierzu Kociewskim (wschodnia część Pomorza). Prace Geograficzne 201. Wyd. Nauk. IGiZP, Warszawa.

Błaszkiewicz M., 2007. Geneza i ewolucja mis jeziornych na młodoglacjalnym obszarze Polski - wybrane problemy. Studia Limnologia et Telematologica 1(1): 5-16.

de Klerk P., 2004. Confusing concepts in Lateglacial stratigraphy and geochronology: origin, consequences, conclusions (with special emphasis on the type locality Bøllingsø). Review of Palaeobotany and Palynology 129: 265-298.

Deneko P., Andrzejewski L., 2012. Morfogeneza ukierunkowanych form w obrębie północnego fragmentu subglacjalnej rynny rzeki Lubianki (Wysoczyzna Dobrzyńska). W: K. Fortuniak, J. Jędruszkiewicz, M. Zieliński (red.), Przestrzeń w badaniach geograficznych. Wyd. UŁ, Łódź: $37-45$.

Dyakowska J., 1959. Podręcznik analizy pyłkowej. Metody i problemy. Wyd. Geol., Warszawa.

Dybova-Jachowicz S., Sadowska A. (red.), 2003. Palinologia. Wyd. PAN, Kraków. 
Filbrandt-Czaja A., 2009. Historia działalności człowieka w rejonie Jeziora Grodzieńskiego koło Chełmży w świetle analizy pyłkowej. W: J. Gackowski (red.), Archeologia epoki brązu i żelaza. Studia i materiały. T. 1. Wyd. PWN, Warszawa: 211-229.

Galon R., 1983. On the origin of subglacial channels. W: D.J. Briggs, R.S. Waters (red.), Studies in Quaternary Geomorphology. International Symposia Series, Cambridge: 85-95.

Gamrat W.W., 2011. Historia roślinności w rejonie Gronowa w świetle analizy pyłkowej. W: Człowiek i jego wpływ na środowisko przyrodnicze w przeszłości i czasach historycznych. V Polska Konferencja Paleobotaniki Czwartorzędu, Górzno: 114-116.

Granoszewski W., Nita M., Nalepka D., 2004. Viscum album L. - Mistletoe. W: M. Ralska-Jasiewiczowa, M. Latałowa, K. Wasylikowa, K. Tobolski, E. Madeyska, H.E.Jr. Wright, Ch. Turner (red.), Late Glacial and Holocene history of vegetation in Poland based on isopollen maps. Wyd. IB PAN, Kraków: 237-244.

Karasiewicz M.T., Hulisz P., Noryśkiewicz A.M., Krześlak I., Świtoniak M., 2014. The record of hydroclimatic changes in the sediments of a kettle-hole in a young glacial landscape (north-central Poland). Quaternary International 328-329: 264-276.

Karasiewicz M.T., Noryśkiewicz A.M., Noryśkiewicz B., Hulisz P., Stachowicz-Rybka R., Bendych M., 2011. Późnoglacjalne i holoceńskie zmiany środowiska w okolicach Zbójenka na Pojezierzu Dobrzyńskim. W: Człowiek i jego wpływ na środowisko przyrodnicze w przeszłości i czasach historycznych. V Polski Konferencja Paleobotaniki Czwartorzędu, Górzno: 95-105.

Komarek J., Jankovska V., 2003. Review of the Green Algal Genus Pediastrum: implication for Pollen analytical Research. Bibliotheca Phycologica 108. Berlin-Stuttgart.

Kondracki J., 1998. Geografia regionalna Polski. Wyd. PWN, Warszawa.

Kozarski S., 1994. Geneza rynien subglacjalnych na niżu polsko-niemieckim. W: B. Nowaczyk (red.), Warsztaty terenowe. Geomorfologia i osady strefy litoralnej jezior. Charzykowy, 6-10 września. Wyd. UAM, Poznań: 9-24.

Latałowa M., 2003. Holocen. W: S. Dybova-Jachowicz,A. Sadowska (red.), Palinologia. Wyd. IB PAN, Kraków: 273-307.

Madeja J., Bałaga K., Harmata K., Nalepka D., 2004. Pteridium aquilinum (L.) Kuhn - Bracken. W: M. Ralska-Jasiewiczowa, M. Latałowa, K. Wasylikowa, K. Tobolski, E. Madeyska, H.E. Jr. Wright, Ch. Turner (red.), Late Glacial and Holocene history of vegetation in Poland based on isopollen maps. Wyd. IB PAN, Kraków: 327-336.

Marks L., 1996. Rola martwego lodu w kształtowaniu mis jeziornych obecnych pojezierzy. Acta Geographica Lodziensia 71: 181-193.

Milecka K., 2005. Historia jezior lobeliowych zachodniej części Borów Tucholskich na tle postglacjalnego rozwoju szaty leśnej. Wyd. UAM, Poznań.

Mitok-Szpiganowicz G., Zachowicz J., Ralska-Jasiewiczowa M., Nalepka D., 2004. Corylus avellana L. - Hazel. W: M. Ralska-Jasiewiczowa, M. Latałowa, K. Wasylikowa, K. Tobolski, E. Madeyska, H.E. Jr. Wright, Ch. Turner (red.), Late Glacial and Holocene history of vegetation in Poland based on isopollen maps. Wyd. IB PAN, Kraków: 79-89

Morrtensen M.F., Birks H.H., Christensen Ch., Holm J., Noe-Nygaard N., Odgaard B.V., Olsen J., Rasmussen K.L., 2011. Lategliacial vegetation development in Denmark - New evidence based on macrofossil and pollen fron Slotseng, a small-scale site in southern Jutland. Quaternary Science Reviews 30: 2534-2550.

Nalepka D., 2005. Late Glacial and Holocene paleoecological conditions and changes of vegetation cover dunder Elary forming activity in the south Kujawy region (central Poland). Acta Palaeobotanica. International Journal of Palaeobotany and Palynology. Supp. 6. Wyd. IB PAN, Kraków.

Nalepka D., Walanus A., 2003. Data processing in pollen analysis. Acta Palaeobotanica 43(1): 125-134.

Niewiarowski W., 1959. Formy polodowcowe i typy deglacjacji na Wysoczyźnie Chełmińskiej. Stud. Soc. Sci. Torun. 4(1).

Niewiarowski W., 1968. Morfologia i rozwój pradoliny i doliny dolnej Drwęcy. Stud. Soc. Sci. Torun. 6(5).
Niewiarowski W., 1986. The phases of transformation of subglacial channels into river valleys: a case study of the Lower Vistula region. AUNC, Geografia 21: 61-72.

Niewiarowski W., 1988. Levels in subglacial channels and their significance in determining the channel origin and evolution. Geographia Polonica 55: 114-127.

Niewiarowski W., 1989. Wahania poziomu jezior w późnym glacjale i w holocenie na przykładzie jezior Pojezierza Brodnickiego. Studia i Materiały Oceanologiczne 56: 277-288.

Niewiarowski W., 1993. Geneza i ewolucja rynny żnińskiej w okresie pełnego i późnego vistulianu. AUNC, Geografia 25: 3-30.

Niewiarowski W., 1995a. Diagnostic features of subglacial channels of glacial and glaco-glaciofluvial origin, exampled by channels of the Chełmno-Dobrzyń and the eastern Gniezno Lakelands. Quaestiones Geographicae, Special Issue 4: 225-231.

Niewiarowski W., 1995b. Wahania poziomu wody w Jeziorze Biskupińskim i ich przyczyny. W: W. Niewiarowski (red.), Zarys zmian środowiska geograficznego okolic Biskupina pod wpływem czynników naturalnych i antropogenicznych w późnym glacjale i holocenie. Oficyna Wyd. „Turpress”, Toruń: 215-234.

Noryśkiewicz A.M., 2006. Historia cisa w okolicy Wierzchlasu w świetle analizy pyłkowej. Wyd. UMK, Toruń.

Noryśkiewicz A.M, 2008. Stan badań palinologicznych na Pojezierzu Chełmińskim i na przyległych częściach dolin Wisły i Drwęcy. W: A. Wacnik, E. Madeyska (red.), Polska północno-wschodnia w holocenie. Człowiek i jego środowisko. Botanical Guidebooks 30: 97-114.

Noryśkiewicz A.M., 2013. Historia roślinności i osadnictwa ziemi chełmińskiej w późnym holocenie. Studium palinologiczne. Wyd. UMK, Toruń.

Noryśkiewicz B., 1982. Lake Steklin - a reference site for the Dobrzyń-Chełmno Lake District, NE. Poland report on palaeoecological studies for the IGCP-project no. 158B. Acta Palaeobotanica 22: 65-83.

Noryśkiewicz B., 1987. History of vegetation during the Late-Glacial and Holocene in the Brodnica Lake District in the light of pollen analysis of Lake Strażym deposits. Acta Palaeobotanica 27: 283-304.

Ralska-Jasiewiczowa M., Goslar T., Madeyska T., Starkel L. (red.), 1998. Lake Gościąż, central Poland. A monographic study. Pt 1. Wyd. IB PAN, Kraków.

Rutkowski J., Krzysztofiak L., 2009. Jezioro Wigry: historia jeziora w świetle badań geologicznych i paleoekologicznych. Stowarzyszenie "Człowiek i Przyroda”, Suwałki.

Stančikaitė M., Šinkūnas P., Šeirienė V., Kisielinė D., 2008. Patterns and chronology of the Lateglacial environmental development At Pamerkiai and Kašučiai, Lithuania. Quaternary Science Reviews 27: 127-147.

Szeroczyńska K., Zawisza E., 2007. Paleolimnologia - historia rozwoju jezior w Polsce w świetle badań fauny wioślarek. Studia Limnologica et Telmatologica 1: 51-60.

Tobolski K. (red.), 1991. Wstęp do paleoekologii Lednickiego Parku Krajobrazowego. Wyd. UAM, Poznań.

Tobolski K., 2000. Przewodnik do oznaczania torfów i osadów jeziornych. Wyd. PWN, Warszawa.

van Geel B., Buurman J., Brinkkemper O., Schelvis J., Aptroot A., van Reenen G., Hakbijl T., 2003. Environmental reconstruction of a Roman Period settlement site in Uitgeest (The Netherlands), with special reference to coprophilous fung. Journal of Archaeological Science 30: 873-883.

Wacnik A., 2009. Vegetation development in the Lake Miłkowski area, north-eastern Poland, from the Plenivistulian to the late Holocene. Acta Palaeobotanica 49: 287-335.

Walanus A., Goslar T., 2009. Datowanie radiowęglowe. Wyd. AGH, Kraków.

Więckowski K., 1966. Osady denne Jeziora Mikołajewskiego. Prace Geograf. IG PAN 57. Warszawa.

Wojciechowski A., 2000. Zmiany paleohydrologiczne w środkowej Wielkopolsce w ciągu ostatnich 12000 lat w świetle badań osadów jeziornych rynny kórnicko-zaniemyskiej. Wyd. UAM, Poznań

Wysota W., Noryśkiewicz B., 2011. Geomorphology and vegetation history of the rypienica channel, the Dobrzyń Lakeland, North Poland. Bulletin of Geography, Physical Geography Series 4: 71-88. 